\title{
Production of Mayonnaise from Date Pit Oil
}

\author{
Amany Mohamed Mohamed Basuny, Maliha Ali Al-Marzooq
}

Food Science \& Nutrition Department, Faculty Agriculture Science \& Foods, King Faisal University, Hofuf, Saudi Arabia.

Email: dramany_basuny@yahoo.com

Received August $4^{\text {th }}, 2011$; revised September 14 $4^{\text {th }}, 2011$; accepted September 22 $2^{\text {nd }}, 2011$.

\begin{abstract}
Chemical composition of the residual pits from processing of date (Phoenix dactylifera L.) variety khalas from AL-Hasa region-Saudi Arabia was investigated. The extracted oil from residual pits was analyzed for its physico-chemical properties, (refractive index, colour, acid value, peroxide value, iodine number, saponification number and unsaponifiable matter), total phenols, tocopherol content, fatty acid composition, hydrocarbons, and sterol compounds by gas liquid chromatography, and oxidative stability by Rancimat method at $100^{\circ} \mathrm{C} \pm 2{ }^{\circ} \mathrm{C}$. Mineral content of date pits was analyzed by atomic absorption spectrophotometry. Date pit oil was used to replace conventional oil in producing mayonnaise, and sensory qualities were evaluated in comparison with commercial mayonnaise prepared from corn oil. The data demonstrated that mayonnaise containing date pit oil was superior in sensory characteristics as compared with control manufactured from corn oil. Results showed that the date pit oil could be used as nontraditional oil in some food processing such as mayonnaise products.
\end{abstract}

Keywords: Date Stone, Fatty Acid Composition, Oxidative Stability, Mayonnaise

\section{Introduction}

The date (Phoenix dactylifera L.) has been an important crop in arid and semiarid regions of the world. It has always played an important part in the economic and social lives of the people of these regions. Saudi Arabia is considered to be one of the date producing countries; the number of these trees is estimated to be over 4 million and around 100,000 tons of dates are produced annually. The fruit of the date palm is well known as a stable food. It is composed of a fleshy pericarp and seed [1]. The chemical composition and nutritional value of date flesh have been reported by several authors for example [2,3]. Few works have been published on date palm seeds [4]. These works were focused on their chemical composition only. Pits of date palm (seed) are a waste product of many industries, after technological transformation of date fruits [5] or their biological transformation [6]. Then a large quantity of date seeds could be easily collected from the date processing industries or from the waste products (represent nearly $30 \%$ of the production in Saudi Arabia) coming either directly from the palm grove or from the gas-conditioning stations. It is well known that the average weight of date seeds is about $10 \%-15 \%$ of date weight [2]. Also, date seeds contain $10 \%$ crude oil [7].

The aim of the present work was to study chemical composition of date pits. Also, extracted oil from seeds, then study physico-chemical properties of date pits oil. Use of date pits oil for industrial applications such as production of mayonnaise.

\section{Materials and Method}

\subsection{Source of Oils and Pits}

The pits of khalas variety was directly isolated from 50 $\mathrm{kg}$ of waste date fruit having the Al-Hasa region, Saudi Arabia and collected at the "tamr stage" (full ripeness). The pits were soaked in water, washed to free them of any adhering date flesh, air-dried and then dried (12 h) at about $50^{\circ} \mathrm{C}$. Date pits were separately milled in a heavyduty grinder to pass $1-2 \mathrm{~mm}$ screens and then preserved at $-20^{\circ} \mathrm{C}$ until analysis. Palm kernel oil was obtained from local market, Al-Hasa-Saudi Arabia.

\subsection{Chemical Analysis of Stone}

AOAC (2005) [8] methods were used to determine moisture, protein, fat. Crude fiber and ash content, while carbohydrate was calculated by difference.

\subsection{Minerals Analysis}

The method described by AOAC (2005) [8] was used for minerals analysis ( $\mathrm{Ca}, \mathrm{Na}, \mathrm{K}, \mathrm{Fe}$, and $\mathrm{Mg}$ ). The ash was digested with $3 \mathrm{ml}$ of HCL and made up to the mark in 
$100 \mathrm{~cm}^{3}$ standard flask with $0.36 \mathrm{ml} \mathrm{HCL}$ before the minerals elements were determined by Atomic Absorption spectrophotometer (PYE Unicom, UK, Modle SP9). Phosphorus content $(\mathrm{P})$ was determined by the phosphomolybdovanate method (AOAC 2005) [8].

\subsection{Lipid Extraction}

Lipid extraction was carried out with SER 148 Solvent Extractor (Velp Scientifica, Europe) equipped with Six Soxhlet posts. About $15 \mathrm{gm}$ of powdered date pits were used for oil extraction, with petroleum ether $40^{\circ} \mathrm{C}-60^{\circ} \mathrm{C}$ (merck), in each Soxhlet post [1]. The operational conditions were: immersion time: $30 \mathrm{~min}$ with thimble immersed in boiling solvent, washing time: 60 min of reflux washing. The relative percentage weight of lipids compared with weight of dried stone was about $12.70 \%$ [1]. The obtained stone oils were drained under a steam of nitrogen and then stored in a freezer $\left(-20^{\circ} \mathrm{C}\right)$ for subsequent analysis.

\subsection{Physico-Chemical Properties of Oil}

Refractive index at $40^{\circ} \mathrm{C}$, colour, acid value $(\%$ as oleic acid), peroxide value (meq. $\mathrm{O}_{2} / \mathrm{kg}$ oil), iodine number $\left(\mathrm{I}_{2} / 100 \mathrm{~g}\right.$ oil) and saponification number $(\mathrm{mg} \mathrm{KOH} / \mathrm{g}$ oil), were determined according to AOAC (2005) [8].

\subsection{Oxidative Stability of Oil}

Oxidative stability was done using a Rancimat 679 apparatus (Metrohm AG, Herison, Swizerland) respecting these conditions: oil samples of $5.00 \mathrm{gm}$, temperature $100^{\circ} \mathrm{C} \pm 2{ }^{\circ} \mathrm{C}$, and air flow rate of $20 \mathrm{~L} / \mathrm{hr}$ [9].

\subsection{Total Phenol}

Total phenols in date pits oil were determined calorimetrically at $725 \mathrm{~nm}$ with the Folin-ciocalteau reagent as previously done by Gutfinger (1981) [10].

\subsection{Fatty Acid Composition}

Fatty acid composition was analyzed on the gas liquid chromatography (GLC). The oil was esterified before GC analusis using the method described by Stahle (1967) [11]. The methyl esters of fatty acids were prepared using benzene: methanol: concentrated sulfuric acid 86:10:4 and the methylation process were carried out for one hour at $80^{\circ} \mathrm{C}-90^{\circ} \mathrm{C}$. A pye Unicom PU 4550 equipped with dual flame ionization detector was used. The fractionation of fatty acid methyl esters was conducted using a coiled glass column $(1.5 \mathrm{~mm} \times 4 \mathrm{~mm})$ packed with diatomic (100 - 120 mesh) and coated with $10 \%$ polymethylene glycole adipate. The oven temperature was programmed at $8^{\circ} \mathrm{C} / \mathrm{min}$. from $70^{\circ} \mathrm{C}$ to $190^{\circ} \mathrm{C}$ then isothermally at $190^{\circ} \mathrm{C}$ for $10 \mathrm{~min}$. with nitrogen at $30 \mathrm{ml} / \mathrm{min}$. as a carrier gas, the flow rates for hydrogen and air were
$30 \mathrm{ml} / \mathrm{min}$. and $320 \mathrm{ml} / \mathrm{min}$ respectively. Detector and injector temperature were $300^{\circ} \mathrm{C}$ and $250^{\circ} \mathrm{C}$ respectively. The chromatogram of the authentic fatty acids was used to characterize the unknown fatty acids according to their retention times. Present normalization of each fatty acid was calculated by the normalization with response factors method using the PU 48\% competing integration. The fatty acid composition was expressed as percentage of total fatty acid [12].

\subsection{Tocopherols Content}

The total tocopherol content was determined in date pits according to the method of [13].

\subsection{Unsaponifiable Matter Composition}

The unsaponifiable matter was extracted from date pits oil after saponification at room temperature according to the methods outlined by Mordert, (1968) [14]. The unsaponifiable matter was analyzed using Heweltt Pakard gas chromatography model 5890 equipped with flame ionization detector. The column used for separating the unsaponifiable matter was a $25 \mathrm{~m} \times 0.20 \mathrm{~mm}$ I.D fused silica capillary column coated with dimethyl silica fluid. The chromatographic conditions were split 200/I, sample size IUL, carrier gas was nitrogen at a flow rate of 1 $\mathrm{ml} / \mathrm{min}$, injection part temperature $250^{\circ} \mathrm{C} / \mathrm{min}$ then isothermally for $20 \mathrm{~min}$ at $280^{\circ} \mathrm{C}$, detector temperature $300^{\circ} \mathrm{C}$ auxiliary (detector make UP) gas flow rate nitrogen at $20 \mathrm{ml} / \mathrm{min}$ hydrogen and air flow rates were 30 $\mathrm{ml} / \mathrm{min}$, and $400 \mathrm{ml} / \mathrm{min}$. respectively. Peak areas measurements, relative percentage of each peak and retention times were determined using a Hewlett Pakard 3392 an integrator.

\subsection{Mayonnaise Preparation}

Mayonnaise samples were prepared from date pits oil, using the suggested formula as shown in Table 1.

Table 1. Formula used in the preparation of mayonnaise samples.

\begin{tabular}{cc}
\hline Ingredients & Weight \\
\hline Salad oil & 66.66 \\
Whole egg & 26.16 \\
Salt & 1.20 \\
Sugar & 0.80 \\
Mustard flour & 0.33 \\
Mustard & 2.33 \\
Vinegar & 2.02 \\
White pepper & 0.50 \\
\hline
\end{tabular}


Salt, sugar, mustard and white pepper were first mixed with egg and vinegar in electric mixer on liquefying velocity for 5 seconds. The oil was then added slowly to the system at first and more rapidly after the mass began to thicken. All ingredients were mixed in blender for $5 \mathrm{~min}$. mayonnaise samples were packed into clear glass bottles with screw cap, stored at room temperature $\left(20^{\circ} \mathrm{C} \pm 2^{\circ} \mathrm{C}\right)$. Mayonnaise samples were taken at next day for organoleptic evaluation.

\subsection{Organoleptic Evaluation of Mayonnaise Samples}

Sensory evaluation was preformed on mayonnaise samples produced from date pits oil compared with a commercial product called mayonnaise produced by AATCOL. L. C. Sultanate of Oman. Prior to the sensory tests, the panelists (twenty persons) were trained to evaluate the attributes of the mayonnaise produced in this study and become proficient. The sensory evaluation of mayonnaise samples were conducted two times and the mean score values were reported in the text. The mayonnaise samples were rated on a 10 point scale $(1,2$ : bad; 3,4 : poor; 5, 6: fair; 7, 8: good; 9, 10 excellent). The mayonnaise samples, placed randomly in codified plate with three-digit cods, were served to each panelist. Judges were placed in different places to avoid communication during the evaluation and asked to score chips for taste, texture, appearance, color, odour and overall acceptability [15].

\subsection{Statistical Analysis}

All values prone statistical analysis is mean \pm standard error for three independent samples. Analysis of variance and the least significant difference (LSD) test at $P \geq 0.05$ was calculated to allow comparison between the mean values of the studied parameter (Cochran \& Cox, 1992) [16].

\section{Results and Discussion}

\subsection{Chemical Composition of Date Stone}

Table 2 presents the average compositions of Phoenix dactylifera $L$. date pits of the khalas variety. Date stone from khalas variety contained $3.66 \%$ moisture, respectively. The ash, protein and fat content (dry weight basis) in khalas variety were $0.98 \%, 6.37 \%$ and $9.76 \%$, respectively. Accordingly, total carbohydrate content of date pits $62.90 \%$. These results were in general agreement with those reported by $[4,17,18]$.

\subsection{Mineral Content}

The date pits also contained significant amount of important minerals (Table 3). The potassium concentration
Table 2. Chemical composition of date pits.

\begin{tabular}{cc}
\hline Compounds & Date stone \\
\hline Moisture & $3.66 \pm 0.09$ \\
Protein & $6.37 \pm 1.15$ \\
Fat & $9.76 \pm 2.00$ \\
Ash & $0.98 \pm 0.02$ \\
Fiber & $19.99 \pm 5.01$ \\
Carbohydrates & $62.90 \pm 7.80$ \\
\hline
\end{tabular}

Values are \pm mean SE of three estimations.

Table 3. Mineral content of date pits.

\begin{tabular}{cc}
\hline Constituents & Concentration (mg/kg samples) \\
\hline Sodium (Na) & $160.00 \pm 10.50$ \\
Calcium (Ca) & $189.35 \pm 11.02$ \\
Potassium (k) & $2489.50 \pm 22.05$ \\
Iron (Fe) & $19.23 \pm 0.19$ \\
Copper (Cu) & $5.02 \pm 0.001$ \\
Phosphorus (P) & $1256.23 \pm 16.05$ \\
Magnesium (Mg) & $811.30 \pm 13.09$ \\
Zinc ( $\mathrm{Zn})$ & $1.67 \pm 0.001$ \\
Manganese $(\mathrm{Mn})$ & $7.12 \pm 0.02$ \\
\hline
\end{tabular}

Values are \pm mean SE of three estimations.

was the highest, followed in descending order by phosphorus, magnesium, calcium, sodium and iron. This order has already been reported by [17,18]. However, Al-Showiman (1990) [19] found that the calcium content is highly significant, while potassium, sodium and magnesium come into second place.

\subsection{Physico-Chemical Properties of Date Pit and Palm Kernel Oils}

Table 4 shows the physico-chemical properties of date pits and palm kernel oils. The obtained data indicated that the refractive index, color, viscosity, free fatty acids, peroxide value, iodine number and saponification number of date pits and palm kernel oils were similar. The results indicated that the refractive index of both oils were 1.4595 and 1.4500 , respectively. The colour of date pits and palm kernel oils are clear bright yellow. The results indicated that the acid value (\% as oleic acid) of date pits oils was lower $(0.05 \%)$ than those of palm kernel oil. The peroxide value of date pits oil is higher (1.73 meq. $/ \mathrm{kg}$ oil) than that of palm kernel oil (1.42 meq. $/ \mathrm{kg}$ oil). The iodine value of date pits oil is higher $\left(46.50 \mathrm{gI}_{2} /\right.$ 
$100 \mathrm{~g}$ oil) compared with palm kernel oil (19.30 $\mathrm{gI}_{2} / 100$ $\mathrm{g}$ oil). Saponification number of date pits oil is lower (312.00) than that of palm kernel oil (254.00). These results were in general agreement with those reported by $[1,20]$.

\subsection{Fatty Acid Composition}

Fatty acid composition of the Khalas date pits and palm kernel oils shown in Table 5. In all ten fatty acids were present, four of which were unsaturated. The most abun-

Table 4. Some physical and chemical properties of date pits oil compared with palm kernel oil.

\begin{tabular}{ccc}
\hline \multirow{2}{*}{ Parameters } & \multicolumn{2}{c}{ Oils } \\
\cline { 2 - 3 } & Date pits oil & Palm kernel oil \\
\hline Refractive index at $40^{\circ} \mathrm{C}$ & $1.4595 \pm 0.001$ & $1.4500 \pm 0.001$ \\
Color at yellow $35 \mathrm{Red}$ & $0.90 \pm 0.01$ & $1.50 \pm 0.10$ \\
Free fatty acids $(\%$ as oleic acid) & $0.05 \pm 0.002$ & $0.74 \pm 0.003$ \\
Peroxide value meq. $\mathrm{O}_{2} / \mathrm{kg}$ oil & $1.73 \pm 0.15$ & $1.42 \pm 0.13$ \\
Iodin number $\mathrm{I}_{2} / 100 \mathrm{~g}$ oil & $46.50 \pm 2.13$ & $19.30 \pm 1.05$ \\
Saponification number & $213.00 \pm 4.50$ & $254.00 \pm 5.01$ \\
Unsabonifiable matter $(\%)$ & $1.65 \pm 0.13$ & $1.70 \pm 0.15$ \\
\hline
\end{tabular}

Values are \pm mean SE of three estimations.

Table 5. Fatty acids composition of date pits oil compared with palm kernel oil.

\begin{tabular}{|c|c|c|}
\hline \multirow{2}{*}{ Fatty acid (\%) } & \multicolumn{2}{|c|}{ Type of oils } \\
\hline & Date pits oil & Palm kernel oil \\
\hline $\mathrm{C} 8: 0$ & $0.00 \pm 0.00$ & $2.87 \pm 0.15$ \\
\hline $\mathrm{C} 10: 0$ & $0.25 \pm 0.001$ & $3.11 \pm 0.19$ \\
\hline $\mathrm{C} 12: 0$ & $35.31 \pm 1.15$ & $45.88 \pm 1.90$ \\
\hline $\mathrm{C} 14: 0$ & $0.04 \pm 0.001$ & $16.27 \pm 0.85$ \\
\hline $\mathrm{C} 16: 0$ & $12.58 \pm 0.72$ & $15.66 \pm 0.71$ \\
\hline C18:0 & $3.30 \pm 0.10$ & $2.16 \pm 0.19$ \\
\hline C18:1 & $39.50 \pm 1.50$ & $26.25 \pm 1.31$ \\
\hline $\mathrm{C} 18: 2$ & $8.20 \pm 0.61$ & $2.57 \pm 0.18$ \\
\hline $\mathrm{C} 18: 3$ & $0.81 \pm 0.12$ & $0.89 \pm 0.11$ \\
\hline $\mathrm{C} 20: 0$ & $0.02 \pm 0.001$ & $0.00 \pm 0.00$ \\
\hline Total saturated & $51.00 \pm 3.50$ & $70.29 \pm 6.30$ \\
\hline Total unsaturated & $49.00 \pm 3.10$ & $29.71 \pm 1.50$ \\
\hline Total fatty acids & 100.00 & 100.00 \\
\hline
\end{tabular}

Values are \pm mean SE of three estimations. dant fatty acids of date pits oil were oleic (C18:1), linoleic (C18:2), and palmitic (C16:0), myristic (C14:0) and Lauric (C12:0) which together composed about $92 \%$ of the total fatty acids. The major fatty acid found in date pits oil was oleic acid (39.50\%). This is in agreement with previous reporteds (Al-Hooti et al., 1998). However, palm kernel oil found a higher content of lauric acid $(45.88 \%)$. In this study date pits oil was regarded as an oleic-lauric oil while palm kernel oil was an lauric-aleic oil. In general, date pits oil is (C18:1, C18:2, C16:0, C14:0 and C12:0); oleic fatty acid (C18:1) was always most abundant in date stone oil. Date pits oil showed a higher unsaturated fatty acid content (UnsAFA: $49.00 \%$ ) than palm kernel oil (UnsAFA: 29.71\%).

The degree of unsaturation of date pits oil was lower than that of common vegetable oils, since date pits oil had much lower linoleic acid content. In spite of this low level of unsaturation, date pits oil may have interesting potential for different types.

\subsection{Unsaponifiable Matter}

The hydrocarbons and sterols in the unsaponifiable matter of date pit and palm kernel oils are analyzed by using gas liquid chromatography. The obtained data are illustrated in Table 6. From Table 6 total hydrocarbons of palm kernel oil had slightly percentage (62.70\%) than those of date pit oil was reached to $60.79 \%$, respectively. Data in Table 6 indicated that the total sterols of date pit oil had higher percentage (39.26\%) than palm kernel oil $(38.10 \%)$, respectively, the major hydrocarbons of date pit and palm kernel oils were squalene, C24, C26, C30, $\mathrm{C} 18$, and $\mathrm{C} 14$, respectively. On the other hand the predominant sterols compound for date pit and palm kernel oils was only $\beta$-sitosterols, which reached $25.83 \%$ and $21.33 \%$ respectively. Unsaponifiable matter of date pit oil had higher percentage of $\beta$-sitosterols than palm kernel oil.

\subsection{Polyphenols, Tocopherols and Oxidative Stability}

The results of the Rancimat method are shown in Table 7. Stability, expressed as the oxidation induction time (h), was about $41.60 \mathrm{~h}$ for Khalas pits oil and about $44.40 \mathrm{~h}$ for palm kernel oil. This difference may be explained by the fact that khalas pits oil contained more unsaturated fatty acid and saturated fatty acid than palm kernel oil. The latter may also have a higher antioxidant content, e.g. $\alpha$-tochopherol and phenolic compounds, which are well known as food lipid antioxidants. A linear regression based on the oleic/linoleic ratio and the contents of phenols and tocopherols, in virgin olive oil, showed a good correlation with the oxidative stability measured by Rancimat [20]. 
Table 6. Unsaponifiable matter fraction (Hydrocarbons and sterols) of date pits oil compared with palm kernel oil.

\begin{tabular}{|c|c|c|}
\hline \multirow{2}{*}{ Compounds } & \multicolumn{2}{|c|}{ Type of oils } \\
\hline & Date pits oil & Palm kernel oil \\
\hline $\mathrm{C}_{8}$ & $0.04 \pm 0.001$ & $0.05 \pm 0.001$ \\
\hline $\mathrm{C}_{10}$ & $0.02 \pm 0.001$ & $0.04 \pm 0.001$ \\
\hline $\mathrm{C}_{12}$ & $0.51 \pm 0.01$ & $1.11 \pm 0.10$ \\
\hline $\mathrm{C}_{14}$ & $1.12 \pm 0.10$ & $1.83 \pm 0.80$ \\
\hline $\mathrm{C}_{16}$ & $0.48 \pm 0.01$ & $0.42 \pm 0.01$ \\
\hline $\mathrm{C}_{18}$ & $3.15 \pm 1.01$ & $3.09 \pm 1.02$ \\
\hline $\mathrm{C}_{20}$ & $0.09 \pm 0.001$ & $0.40 \pm 0.01$ \\
\hline $\mathrm{C}_{22}$ & $6.79 \pm 2.15$ & $7.85 \pm 2.80$ \\
\hline $\mathrm{C}_{24}$ & $15.72 \pm 4.01$ & $15.85 \pm 4.03$ \\
\hline $\mathrm{C}_{26}$ & $10.79 \pm 2.91$ & $11.79 \pm 3.01$ \\
\hline $\mathrm{C}_{28}$ & $0.35 \pm 0.01$ & $0.45 \pm 0.01$ \\
\hline Squalene & $11.23 \pm 3.03$ & $11.61 \pm 3.05$ \\
\hline $\mathrm{C}_{30}$ & $10.50 \pm 2.90$ & $7.50 \pm 2.72$ \\
\hline Total hydrocarbons & $60.79 \pm 5.50$ & $62.70 \pm 5.62$ \\
\hline Cholesterol & $0.00 \pm 0.00$ & $0.00 \pm 0.00$ \\
\hline Brassicaesterol & $1.20 \pm 0.10$ & $2.10 \pm 019$ \\
\hline Campsterol & $8.70 \pm 2.80$ & $10.67 \pm 2.93$ \\
\hline Stigmasterol & $3.48 \pm 1.01$ & $4.00 \pm 1.15$ \\
\hline$B$-sitosterol & $25.83 \pm 3.59$ & $21.33 \pm 3.21$ \\
\hline Total sterols & $39.26 \pm 4.03$ & $38.10 \pm 4.01$ \\
\hline
\end{tabular}

Values are \pm mean SE of three estimations.

Table 7. Polyphenols, tocopherols and oxidative stability.

\begin{tabular}{ccc}
\hline \multirow{2}{*}{ Parameters } & \multicolumn{2}{c}{ Oil } \\
\cline { 2 - 3 } & Date pits oil & Palm kernel oil \\
\hline Oxidative stability $(\mathrm{hr})$ & $41.60 \pm 2.00$ & $44.40 \pm 2.30$ \\
$A$-tocopherol ppm & $243.00 \pm 6.50$ & $198.00 \pm 4.50$ \\
Polyphenols ppm & $319.00 \pm 7.30$ & $187.00 \pm 4.01$ \\
\hline
\end{tabular}

Values are \pm mean SE of three estimations.

The oxidative stability of date pits oil was higher than that of most vegetable oils and comparable to that of olive oil. This may be explained by the low content of poly unsaturated fatty acid in date pits oil and in olive oil compared to the common vegetable oil.
Table 8. Sensory evaluation of mayonnaise.

\begin{tabular}{ccc}
\hline Character & Date pits oil & Corn oil \\
\hline Taste & $8.30 \mathrm{a} \pm 1.00$ & $8.00 \mathrm{a} \pm 0.87$ \\
Flavor & $7.50 \mathrm{a} \pm 0.81$ & $7.60 \mathrm{a} \pm 0.83$ \\
Colour & $8.10 \mathrm{a} \pm 0.91$ & $7.00 \mathrm{a} \pm 0.62$ \\
Texture & $8.00 \mathrm{a} \pm 0.89$ & $7.90 \mathrm{a} \pm 0.85$ \\
General acceptability & $8.50 \mathrm{a} \pm 0.101$ & $8.10 \mathrm{a} \pm 0.89$ \\
\hline
\end{tabular}

Values are \pm mean SE of three estimations.

\subsection{Sensory Evaluation of Mayonnaise}

Sensory evaluation is an important indicator of potential consumer preferences. Difference in sensory quality attributed of extended mayonnaise produced by date pits oil and the results are given in Table 8. Data indicated that mayonnaise containing date pits oil was superior in sensory characteristics as compared with the control samples prepared by using corn oil.

Values in each raw followed by the same latter not significantly different at $\geq 0.05$.

\section{Conclusions}

Considering the protein, oil, mineral and carbohydrate contents of date pits, we can conclude that date pits could be used to meet part of the nutritional requirements of animal feeds. This by product of date processing industries could be regard as an excellent source of food ingredients with interesting technological functionality that could also be used in food as an important source of dietary fiber. This preliminary study shows that date pits oils contain high relative percentages of oleic acid and natural antioxidants ( $\alpha$-tocopherol, polyphenols). They are also more yellow-coloured than other vegetable oils. Date pits oil could easily be conserved due to their high oxidative stability. Regarding these specificities, the value of this by product in food industries such as mayonnaise.

\section{REFERENCES}

[1] S. Besbes, C. Blecker, C. Deroanne, N. Drira and H. Attia, "Date Seeds: Chemical Composition and Characteristic Profiles of the Lipid Fraction," Food Chemistry, Vol. 84, No. 4, 2004, pp. 577-584. doi:10.1016/S0308-8146(03)00281-4

[2] A. S. Hussein, G. A. Alhadrami and Y. H. Khalil, "The Use of Dates and Date Pits in Broiler Starter and Finisher Diets," Bioresource Technology, Vol. 66, No. 3, 1998, pp. 219- 223. doi:10.1016/S0960-8524(98)00054-6

[3] M. Elleuch, S. Besbes, O. Roisuex, C. Blecher, C. Deroanne, N. Drira and H. Attia, "Date Flesh: Chemical 
Composition and Characteristics of the Dietary Fiber," Food Chemistry, Vol. 111, No. 3, 2008, pp. 676-682. doi:10.1016/j.foodchem.2008.04.036

[4] J. S. Hammada, I. B. Hashim and A. F. Sharif, "Preliminary Analysis and Potential Uses of Date Pits in Foods," Food Chemistry, Vol. 76, No. 2, 2002, pp. 135-137. doi:10.1016/S0308-8146(01)00253-9

[5] S. Al-Hooti, J. S. Sidhu, J. Al-Otaibi, H. Al-Ameer and H. Qabazard, "Processing Quality of Important Date Cultivars Grown in the United Arab Emirates for Jam, Butter and Dates-in-Syrup," Advanced Food Science, Vol. 19, No. 1-2, 1997, pp. 35-40.

[6] N. Nacib, A. Nacib, G. Mostafa, L. Larbi, L. Abimi, M. Renmal and J. Bourdant, "Use of Date Products in Production of Thermophilic Dairy Starters Strain Streptococcus Thermophilus," Bioresource Technology, Vol. 67, No. 3, 1999, pp. 291-295. doi:10.1016/S0960-8524(98)00115-1

[7] M. Al-Farsi, C. Alasalvar, M. Al-Abid, K. Al-Shoaily, M. Al-Amry and F. Al-Rawahy, "Compositional and Functional Characteristics of Dates, Syrups and Their byProducts," Food Chemistry, Vol. 104, No. 3, 2007, pp. 943-947. doi:10.1016/j.foodchem.2006.12.051

[8] AOAC, "Official Methods of Association of Agriculture Chemists," 20th Edition, AOAC, Washington DC, 2005.

[9] E. Mendez, G. Sanhueza, H. Spesisky and A. Valenzula, "Validation of the Rancimat Test for the Assessment of the Relative Stability of Fish Oils," Journal of American Oil Chemical Society, Vol. 73, No. 8, 1996, pp. 10331037. doi:10.1007/BF02523412

[10] T. Gutfinger, "Polyphenols in Virgin Olive Oil," Journal of American Oil Chemical Society, Vol. 58, No. 11, 1981, pp. 966-968. doi:10.1007/BF02659771

[11] R. S. Farag, E. A. Abdel Rahim, A. M. El-Sharabasy, F. M. Hewedy and A. A. Ragab, "Biochemical Studies on Lipids of Hins Egg during Incubation," Seifen De-Fette, Wachse, Vol. 100, 1984, pp. 63-68.
[12] M. L. Wong, R. S. Timns and E. M. Goh, "Colorimetric Determination of Total Tocopherols in Palm Oil (Oleic and Stearin)," Journal of American Oil Chemical Society, Vol. 65, No. 2, 1988, pp. 258-261. doi:10.1007/BF02636412

[13] F. Mordert, "Comparison and Study of Methods of Obtaining Unsaponifiable Matter," Journal Crops Grass, Vol. 6, 1986, pp. 389-397.

[14] R. P. Carpenter, D. H. Lyon and T. A. Hasdell, "Guidelines for Sensory Analysis in Food Product Development and Quality Control," Food Chemistry, Vol. 103. 2006, pp. 71-91.

[15] W. G. Cochran and G. M. Cox, "Experimental Designs," 2nd Edition, Wiley, New York, 1992.

[16] S. Al-Hooti, J. S. Sidhu and H. Qabazard, "Chemical Composition of Seeds Date Fruit Cultivars of United Arab Emirates," Journal of Food Science \& Technology, Vol. 35, No. 1, 1998, pp. 44-46.

[17] S. Devshony, A. Eteshola and A. Shani, "Characterization and Some Potential Application of Date Palm (Phoenix dactylifera L.) Seeds and Seed Oil," Journal of American Oil Chemical Society, Vol. 69, 1992, pp. 595-597. doi:10.1007/BF02636115

[18] S. S. Al-Showiman, "Chemical Composition of Date Palm Seeds (Phoenix dactylifera L.) in Saudi Arabia," Journal Chemical Society, Vol. 8, No. 1, 1990, pp. 15-24.

[19] S. Besbes, C. Blecker, C. Deroanne, G. Lognay, N. Drira and H. Attia, "Heating Effects on Some Quality Characteristics of Date Seed Oil," Food Chemistry, Vol. 91, No. 3, 2005, pp. 469-476. doi:10.1016/j.foodchem.2004.04.037

[20] R. Aparicia, L. Roda, M. A. Albi and F. Gutierrez, "Effect of Various Compounds on Virgin Olive Oil Stability Measured by Rancimat," Journal of Agriculture \& Food Chemistry, Vol. 47, No. 10, 1999, pp. 4150-4155. doi: $10.1021 / \mathrm{jf} 9812230$ 